[American Journal of Science, Vol. 309, October, 2009, P. 711-730, DOI 10.2475/08.2009.04]

\title{
THE DURABILITY OF ROGKS-DEVELOPING A TEST OF ROCK RESISTANCE TO CHEMICAL WEATHERING
}

\author{
WALTER A. FRANKE \\ Institut für Geologische Wissenschaften, Freie Universität Berlin, Geocampus \\ Lankwitz, Malteserstrasse 74-100, 12249 Berlin, Germany; email: \\ wafranke@chemie.fu-berlin.de
}

\begin{abstract}
Dissolution rates of 39 rock-forming minerals were determined at $20^{\circ} \mathrm{C}$ and $100{ }^{\circ} \mathrm{C}$ and different $\mathrm{pH}$ values, using experimental set-ups which achieve near-zero cation concentrations. Weathering rates in nature for rock above surface were estimated from data in this study and data in the literature. Extraction in a Soxhlet extractor with boiling $2.5 \mathrm{~m}$ acetic acid causes an acceleration of such estimated natural weathering rates by a factor of $0.25 \times 10^{3}$ to $7 \times 10^{4}$ for nearly all important rock-forming minerals, including the carbonates. The applicability of such a comparative test for rock resistance to chemical weathering was corroborated by testing 32 different rocks and building stones. Run times of only one to four days were needed for a reliable result.
\end{abstract}

\section{INTRODUCTION}

For millenniums, rocks and man-made bricks have been used for buildings, monuments and tombstones. The choice of stones was determined mainly by their availability, sometimes by their beauty. Less attention has been paid to the long-term resistance of the material to weathering. Therefore the conservation of stone structures has become a multidisciplinary field of interest for saving our architectural heritage. Contemporary architects are forced to rely from sheer necessity on historical experience concerning the weathering stability of different materials because no quick chemical weathering test has been available up to now. This study aimed to develop such a test on a scientific basis.

There are well-established tests for the resistance of rocks to physical weathering due to porosity and fissures, like freeze-thaw cycles; these include the Quervain test using the crystallization pressure of sodium sulphate decahydrate (Quervain and Jenni, 1945) and the Brazilian test for tensile strength. The slake-durability test suggested by Franklin and Chandra (1972) is applicable only to sedimentary rocks containing considerable amounts of clay minerals. Recently a combination of wetness and temperature variations were tested for porous sandstones by Benavente and others, 2008. An index of chemical weathering for silicate rocks was proposed by Parker (1970); it has to be calculated from the whole rock analysis. This index is useful to point out the different stages of weathering of the same rock, but it cannot be used to rank susceptibility towards weathering for a range of very different rocks. The same is true for some other index types that are also based on chemical composition only (Jayawardena and Izawa, 1994; Gupta and Rao, 2001). In 2001 Oelkers presented a method for the calculation of dissolution rates of homogenous glasses or multioxide silicate minerals of known composition under certain conditions. This method cannot be applied to rock dissolution because rocks are an aggregate of different intergrown phases.

It is well known from the petrological record that the mineral composition of rocks depends on their chemical composition as well as on many other parameters, such as temperature, pressure, water content during crystallization, and their cooling history. With the exception of quartz, nearly all major rock-forming silicates are mixed crystals, and their weathering rates depend on their composition and may be influenced by zonal structure. During rock cooling, many minerals are partly altered by reaction with water, for instance saussuritization, chloritization, uralitization, kaoliniza- 
tion, and serpentinization. Many new minerals formed in this way are less prone to weathering than the original ones, but in all cases their surface has been greatly increased. Some minerals become unstable during cooling, and exsolution structures are formed by diffusion processes; during weathering a honeycomb-like structure is formed due to different weathering rates of perthitic lamellae (Berner and Holdren, 1979; Inskeep and others, 1991; Franke and Teschner-Steinhardt, 1994). So again the surface is increased considerably. Texture, grain size, cleavage cracks, and porosity of rocks also depend on their mode of formation; such properties may influence rock weathering too. Most such features can be inspected by a thorough examination of thin sections under a polarizing microscope, but skill and experience are needed for this task as well as knowledge of the rank of resistance of all the minerals towards weathering under near-neutral and more acid conditions. Nevertheless, weak grain boundaries and minute amounts of easily weathered minerals such as carbonates sometimes cannot be assessed even by this inspection (Butenuth, 2001). Moreover, such knowledge cannot be expected from architects, artists, or clients who order monuments or buildings; so a quick weathering test seems desirable. According to the facts delineated above such a test must use macroscopic pieces of the rock with geometric measured surface.

\section{LITERATURE}

Dissolution rates of rock-forming minerals are very low under normal weathering conditions; only large surface areas will permit an experimental set-up producing a result in mass per area and time within an acceptable period. Therefore nearly exclusively narrow grain-sized silt fractions were used to determine the dissolution rate of silicates for 50 years after the first publication (Correns and von Engelhardt, 1939, K-feldspar). Surface determination was managed by a multipoint gas adsorption method; this method was called the BET method after its inventors (Brunauer and others, 1938). At the beginning the dissolution is incongruent because initially alkali and alkaline earth ions are preferentially leached by the reaction with water and $\mathrm{H}^{+}$. So an extremely thin cation-depleted silica layer is formed, but after some time the dissolution becomes congruent for most silicates. Such layers were detected by modern physical methods on different minerals (Schott and others, 1981; Inskeep and others, 1991; Hellmann, 1994, 1995). Recent experiments by Lee and others (2007) concluded that any silica-rich layer on naturally weathered alkali feldspars must have a thickness of less than $2.5 \mathrm{~nm}$. Thicker layers were detected in acid environments on albites (Hellmann and others, 1990). Experiments by different teams during the last ten years indicate that such thicker layers formed in acid environments on feldspars may be a reprecipitated phase; Jordan and others, 1999; Fenter and others, 2003; Tisserand and Hellmann, 2008. This idea is in accord with theoretical computations for albite dissolution kinetics, Zhang and Lüttge, 2007. In summary, it can be concluded that such silica-rich layers have a thickness of only one to two unit cell sizes in the $\mathrm{pH}$ range of 5 to 7 ; only in the acid $\mathrm{pH}$ range the layer thickness increases with decreasing $\mathrm{pH}$ and may reach higher values.

The formation of a continuous cation-depleted layer seems improbable for sheet silicates. Indeed for muscovite, phlogopite and biotite Kalinowski and Schweda (1996) and Ferrow and others (1999) observed a change of the surface area during weathering due to delamination along basal surfaces and a pronounced attack at the edges of the lattice. On prolonged dissolution, biotite was bleached owing to the oxidation of divalent Fe. This was found to be due to a coupled charge transfer process: biotite reduces dissolved $\mathrm{Fe}^{3+}$ (Jeong and Kim, 2003).

The BET method gives a result on an atomic size level; for instance, a geometrical flat surface may be constructed on an atomic scale by terraces; therefore the ratio BET 
area/geometrically measured area is always larger than one. Sverdrup (1990) reviewed the literature concerning such measurements, which he combined with his own measurements. He calculated the geometrical area from the particle size distribution and arrived at values in the range of 2 to 60 for the ratio BET area/geometric area. SEM observations on experimentally weathered surfaces often showed etch pits and sometimes hillocks (Franke and Teschner-Steinhardt, 1994; Brantley, 1995). Any dissolution will attack a crystal lattice preferentially at kinks, ledges, and dislocation steps (Lacmann and others, 1974a, 1974b; Heimann, 1975; Aagard and Helgeson, 1982). This led to the assumption that the density of dislocations may influence the rate of weathering, but Murphy (1989) reported an enhancement of the rate by a factor of 2 to 3 only for shocked plagioclase, though shock treatment enhanced the dislocation density by a factor of 1000 .

The review by Sverdrup (1990), including a multitude of his own measurements, was the first publication to include rates of weathering for most rock-forming minerals depending on $\mathrm{pH}$. Most minerals showed a flat plateau in the near-neutral range of $\mathrm{pH}$ 5 to 7 when the logarithm of the rate was plotted against $\mathrm{pH}$. A linear increase of the rates was observed for both decreasing and increasing $\mathrm{pH}$ on both sides of the plateau. The slope $\Delta$ rate $/ \Delta \mathrm{pH}$ in the $\mathrm{pH} 5$ to $\mathrm{pH} 2$ range is steepest for olivine and flattest for muscovite. No plateau was found for olivine, epidote, iron-free pyroxenes, and micas. The absolute rate values for $20^{\circ} \mathrm{C}, \mathrm{pH} 5.5$ ranged over three and a half powers of ten from the rapidly weathering nepheline to the slowly attacked orthoclase.

The weathering rates are decreased by any considerable cation concentration; especially concentrations of $\mathrm{Al}^{3+}$ higher than $10^{-6} \mathrm{~mol} / 1$ reduce the rate (Sverdrup and Warfvinge, 1987). By contrast, the presence of citric or oxalic acid increases the dissolution rate even for quartz (Bennet and others, 1988). In this connection a report by Kinrade and others (1999) is very interesting; they observed the formation of stable five- and six-coordinated silicate anions by polyalcohols with four $\mathrm{OH}$ groups in the threo conformation, like D-glucose or L-sorbose. The presence of such compounds in nature can be due to roots, lichen or other organic matter; they will cause a quick complexation of orthosilicic acid. An increase of the overall dissolution process seems conceivable because the formation of $\mathrm{H}_{4} \mathrm{SiO}_{4}$ is the assumed first step in the decomposition of any silica-rich layer.

A theory of crystal dissolution rate based on a stepwave dissolution model was proposed by Lasaga and Lüttge (2001); it was triggered and validated by nanometerscale observations of dissolving surfaces (Lüttge and others, 1999), Monte Carlo simulation, and experimental bulk dissolution rates. Already Frank (1958) and Cabrera (1960) had described the dissolution process as a movement of steps, but in contrast to these authors Lasaga and Lüttge (2001) considered also the influence of the degree of undersaturation. At low undersaturations screw dislocations will cause a slow dissolution rate by a spiral dissolution process. Etch pits develop only at larger undersaturations and are the source of a train of steps which travel throughout the mineral surface. Silicate weathering is mostly an irreversible process; the term low undersaturation applies in this case to concentrations of dissolved matter in the solution, which may cause the formation of new phases. This dissolution stepwave model explains why the bulk dissolution rate will depend only slightly on the etch pit density; and why laboratory measured rates are always larger than rates estimated from field observations. The model also explains why laboratory measurements with different cation concentrations of the fluid yielded different weathering rates for the same mineral. Further laboratory measurements corroborated the stepwave model (Jordan and others, 1999; Arvidson and others, 2004; Satoh and others, 2007). 
EXPERIMENTAL SET-UP

It is assumed that the first step in the weathering of silicates in the near-neutral to acid range of $\mathrm{pH}$ is a reversible cation exchange (Stillings and others, 1995), an $\mathrm{n}$-valent cation at the crystal surface being replaced by $\mathrm{n} \mathrm{H}^{+}$ions:

$$
\left[\text { lattice }^{\mathrm{n}-} \mathrm{Me}^{\mathrm{n}+}\right]+\mathrm{n} \mathrm{H}_{3} \mathrm{O}^{+}=\left[\text {lattice }^{\mathrm{n}-} \mathrm{n} \mathrm{H}^{+}\right]+\mathrm{n} \mathrm{H}_{2} \mathrm{O}+\mathrm{Me}^{\mathrm{n}+}
$$

Square brackets indicate the solid phase in equations (1) and (2). During the progress of weathering a disturbed and cation-impoverished layer is formed. Any cation released from the lattice has to pass the disturbed layer by diffusion in order to enter the weathering solution. Vice versa, any $\mathrm{H}^{+}$ion prone to attack the crystal lattice must pass the layer via diffusion in the opposite direction. This process will be most rapidly accelerated if the concentration of all cations besides $\mathrm{H}^{+}$in the weathering solution is kept at zero, no matter whether the ion exchange step or any of the diffusion steps is the slower one. This follows by the law of mass action and the laws governing diffusion. Just such a condition, namely a near-zero cation concentration and a constant $\mathrm{pH}$ value, can be achieved by using a slurry of a cation exchange resin in the $\mathrm{H}^{+}$form:

$$
\left[\operatorname{resin}-\mathrm{SO}_{3}{ }^{-} \mathrm{H}^{+}\right]+\mathrm{Me}^{+}+\mathrm{H}_{2} \mathrm{O}=\left[\operatorname{resin}-\mathrm{SO}_{3}{ }^{-} \mathrm{Me}^{+}\right]+\mathrm{H}_{3} \mathrm{O}^{+}
$$

Equation (2) is formulated for a univalent cation, although in reality di- and trivalent cations are preferentially exchanged. According to equation (2) any cation in the solution is captured by the exchange resin while the $\mathrm{pH}$ value is kept constant, provided that the required surplus of exchange resin is present. It is further assumed that $\mathrm{Si}$ leaves the disturbed layer in the form of orthosilicic acid $\mathrm{H}_{4} \mathrm{SiO}_{4}$, which is only metastable in acid and neutral environments (Hurd and Marotta, 1940). Recent investigations showed that oligomeric silicate structures prevail even in alkaline solutions (Knight and others, 2007). $\mathrm{SiO}_{2}$ particles are ultimately formed by the repeated condensation of ortho- and polysilicic acids.

For experiments at $20^{\circ} \mathrm{C}$ two kinds of weathering solutions were used with respect to the considerations outlined above:

I. A slurry of a cation exchange resin in the $\mathrm{H}^{+}$form (Merck No. 4765) and distilled water. Water in contact with the fresh slurry shows a $\mathrm{pH}$ of 4.0, which decreases slowly with time. Therefore the water was renewed once a month; its average $\mathrm{pH}$ value was 3.8 .

II. A slurry of a mixture of a cation exchange resin in the $\mathrm{H}^{+}$form (Merck No. 4765) with an anion exchange resin in the $\mathrm{OH}^{-}$form (Merck No. 14128) and distilled water. Water in contact with air and this slurry showed a $\mathrm{pH}$ of 5.5.

The minerals were cut into rectangular specimens by a diamond saw. As far as possible single crystals were used; otherwise specimens were cut from monomineralic, polycrystalline pieces. All minerals were identified by an X-ray powder diffractometer; the composition was calculated from analytical data obtained by wave length dispersive X-ray fluorescence spectrometry or by microprobe measurements. Prior to their first use all specimens were cleaned by a ten-minute ultrasonic treatment in distilled water. Surface areas were calculated from the dimensions measured by a slip gauge, the areas used being in the range of 4 to $15 \mathrm{~cm}^{2}$ per specimen. Micas were used as scissor-cut cleavage sheets with an area of 50 to $80 \mathrm{~cm}^{2}$. Polyethylene bottles were used to immerse the mineral specimens in the appropriate exchange resin slurry. The bottles were agitated by hand once a week. The mass difference due to weathering was read by means of an analytical balance. The first weight check was made after 30 days weathering; further weight measurements were obtained approximately every six months, or in the case of rapid weathering minerals at appropriate intervals. Run times 


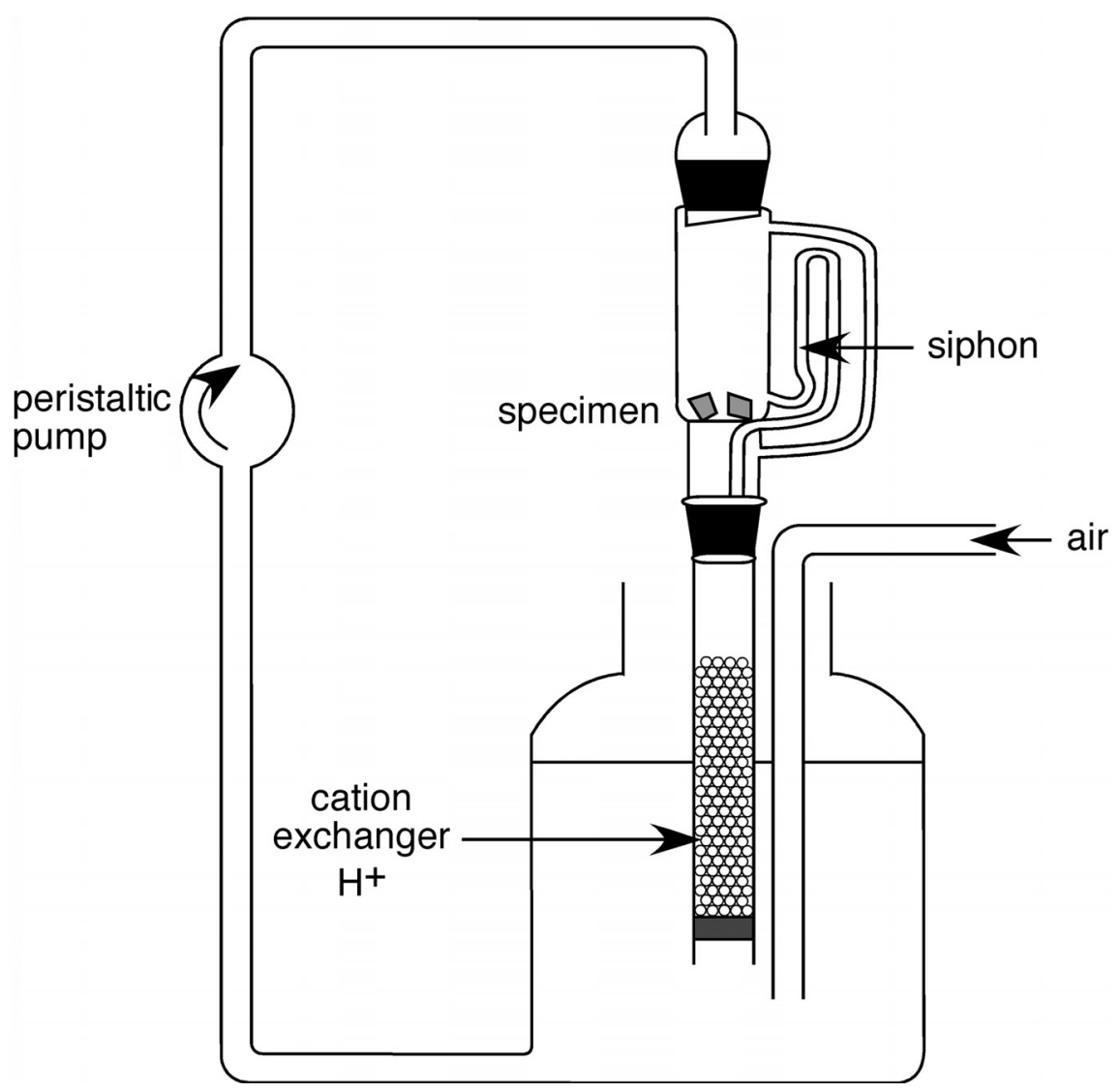

Fig. 1. Experimental setup for the determination of the weathering rates of carbonates.

of up to 4 years were applied. Weight differences used for the calculation of dissolution rates of silicates were based on the 30 days weathering weight. Weathered specimens were inspected by SEM and EDAX.

Carbonates quickly produce $\mathrm{CO}_{2}$ bubbles in contact with any cation exchange resin in the $\mathrm{H}^{+}$form, and so the $\mathrm{HCO}_{3}{ }^{-}$concentration is increased. Therefore another experimental set-up had to be used for carbonates (fig. 1). A stock solution is continuously pumped to the specimen by a peristaltic pump. When the solution reaches the upper point of the siphon, all water runs off and, on its way back to the stock solution bottle, passes a column with the exchange resin. The stock solution is bubbled with air in order to equilibrate it with the $\mathrm{CO}_{2}$ content of air. The pumping rate was regulated for a filling time of approximately ten minutes, so approximately 140 rinses per day with fresh stock solution were achieved. Any $\mathrm{pH}$ value lower than 4 could be adjusted by addition of $\mathrm{H}_{2} \mathrm{SO}_{4}$ if a cation exchange resin in the $\mathrm{H}^{+}$form was used. For pH 5.5 a mixture of cation and anion exchange resin was used. Measurements with such a set-up were made for the carbonates and additionally for apatite, olivine, and nepheline.

All above-described experimental set-ups were well apt to assess a rank of stability not only for minerals but also for rocks. But the time needed for any comparative test would be much too long to be practicable. So it was necessary to look for other 


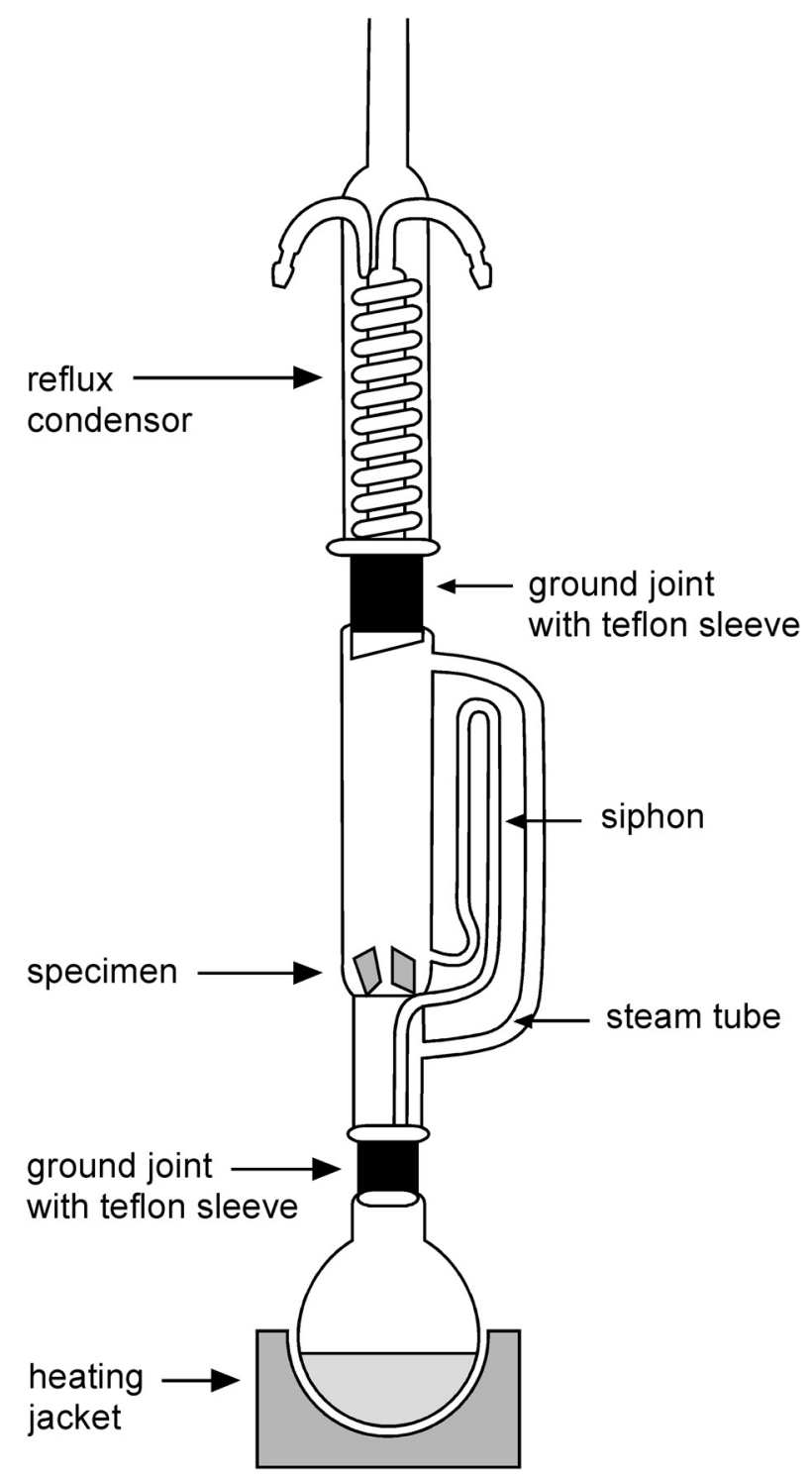

Fig. 2. Experimental setup for the determination of the weathering rates at $100^{\circ} \mathrm{C}$.

conditions accelerating the weathering process. To speed up the dissolution process there are two possibilities:

- to raise temperature using an experimental set-up that rapidly removes all dissolved material

- to reduce $\mathrm{pH}$.

Figure 2 shows a set-up which always provides for the first condition and can also provide for the second one. Its single parts are commercially available as lab ware: heating jacket, boiling bulb, Soxhlet extractor, and reflux condenser, all glass parts connected by NS 29 ground joints. The boiling water in the bulb produces steam which 
is condensed in the condenser, thus producing a continuous rinse of hot distilled water to the specimen in the extractor. A siphon ensures rapid runoff after complete filling. All ground joints must be fitted with Teflon sleeves; otherwise the ground joints may be irreversibly glued together by the silica produced by the dissolution of the specimens. Extractor and both ground joints should be isolated by a threefold aluminium foil wrapping to avoid temperature loss by infra-red emission. The temperature inside the extractor varies with boiling water in the bulb between $97^{\circ} \mathrm{C}$ and $100^{\circ} \mathrm{C}$ parallel to the run-off and filling cycles.

First attempts to use such a set-up for weathering experiments by azeotropic distillation of nitric acid $\left(68 \% \mathrm{HNO}_{3}\right.$, boiling point $\left.120.5^{\circ} \mathrm{C}\right)$ or hydrochloric acid $\left(20 \% \mathrm{HCl}\right.$, boiling point $110^{\circ} \mathrm{C}$ ) had to be abandoned at an early stage. By the etching of silicates both acids produced a thick cover of silica gel slime, covering the surface of the specimen and slipping off from it very irregularly owing to gravity and turbulent currents caused by the runoff. Short-time experiments showed the azeotropic $\mathrm{HCl}$ to be much more aggressive than the $\mathrm{HNO}_{3}$. A rate of $11000 \mathrm{mg} \mathrm{m}^{-2} \mathrm{~d}^{-1}$ was obtained for albite $\mathrm{Ab}_{99} \mathrm{Or}_{1}$, but $170 \mathrm{mg} \mathrm{m} \mathrm{m}^{-2} \mathrm{~d}^{-1}$ only by treatment with azeotropic $\mathrm{HNO}_{3}$.

In the end, two different conditions were used for accelerated weathering:

- pure water in the boiling bulb causes a permanent rinse of the mineral or rock specimen with distilled water at approximately $100{ }^{\circ} \mathrm{C}$ with $\mathrm{pH} 6.12$.

- $2.5 \mathrm{~m}$ acetic acid in the bulb causes a pH of 2.3 in the run-off liquid at $100{ }^{\circ} \mathrm{C}$.

Acetic acid was chosen for the following reason. In the system $\mathrm{CH}_{3} \mathrm{COOH}-\mathrm{H}_{2} \mathrm{O}$ the bubble-point line and dew-point line are nearly identical in the liquid-vapor equilibrium diagram in the range with $\mathrm{CH}_{3} \mathrm{COOH}$ concentrations lower than 18 weight percent. The dissociation constant of acetic acid was determined from $0{ }^{\circ} \mathrm{C}$ to $60^{\circ} \mathrm{C}$ by Harned and Ehlers, 1933; they suggested a formula to extrapolate the constant for higher temperatures. The dissociation constant decreases above $30{ }^{\circ} \mathrm{C}$ with increasing temperatures; an appropriate calculation yields $\mathrm{pH} 2.3$ for $100{ }^{\circ} \mathrm{C}$. During test runs part of the acid in the bulb is neutralized by the dissolved cations; calculations showed a minimal shift of only $\Delta \mathrm{pH}=0.06$ for a 20 percent loss of free acid.

Heating was regulated in order to achieve runoff/filling cycles every ten minutes. It is possible to test several different specimens simultaneously. After some days the silica transported by the runoff precipitates as a white jelly in the bulb; if ironcontaining minerals are rinsed, reddish brown iron oxides and hydroxides are also formed. Both precipitates adhere to the bulb and may cause bumping due to delayed boiling. In this case it is necessary to change the bulb; the iron oxide can be removed by a warm mixture of 20 percent $\mathrm{HCl}$ with oxalic acid and any silica gel dissolves quickly in cold 10 percent $\mathrm{HCl}$ after the addition of a small amount of $\mathrm{NaF}$. Bulbs cleaned in such a way can be used again after a thorough rinsing with water.

\section{RESULTS}

The weathering solutions of the $20^{\circ} \mathrm{C}$ experiments were checked for cation concentrations; the values of $\mathrm{Ca}, \mathrm{Mg}, \mathrm{K}, \mathrm{Na}$, and $\mathrm{Al}$ were always below $10^{-6} \mathrm{~mol} / \mathrm{L}$, no Fe was detected. TEM inspections of filtered weathering fluids showed sphericalshaped silica of approximately 20 to $50 \mathrm{~nm}$ diameter for $20^{\circ} \mathrm{C}$ experiments as well as for the $100^{\circ}$ run-off liquids. Very long run times cause an aggregation; weathering of a Ca-plagioclase for four years at $20^{\circ} \mathrm{C}$ without change of the fluid caused the formation of macroscopic silica floccules. The Si concentration of this solution after filtering with a $0.4 \mu \mathrm{m}$ filter was determined at $10^{-3} \mathrm{~m} \mathrm{SiO}_{2}$. SEM inspections of $20{ }^{\circ} \mathrm{C}$ experiments revealed only very small amounts of a brown iron hydroxide on Fe-containing silicates in fissures and crevices. X-ray diffraction showed this compound to be amorphous. Experiments at $100{ }^{\circ} \mathrm{C}$ with distilled water also caused brown iron hydroxide, partly 
adhering to the rock specimen, partly washed down to the bulb. No iron hydroxide was found on weathered specimens at $100^{\circ}, \mathrm{pH} 2.3$. In these cases the iron oxides precipitated in the boiling bulb only.

The rates of dissolution were calculated in $\mathrm{mg} \mathrm{m}^{-2} \mathrm{~d}^{-1}$. Sometimes the values varied for different specimens of the same mineral; slight differences were also calculated in long-run experiments if different time intervals were used for the calculation. For these reasons both the minimums and maximums of all calculated values were listed in table 1 . No measurable weight loss was recorded for single crystal specimens of quartz, topaz, beryl, and tourmaline in experiments at $20{ }^{\circ} \mathrm{C}$; therefore these minerals were not tested by experiments at $100{ }^{\circ} \mathrm{C}$. Apatite showed no weight loss at $\mathrm{pH} 5.5,20^{\circ} \mathrm{C}$. Originally perfectly flat surfaces showed a rough surface after long-term weathering. This applies to natural crystal surfaces as well as to artificial polished random surfaces. A similar observation was reported by Lüttge and others (1999) for the dissolution of the (010) face of anorthite in an acid environment and controlled at nanometer scale dimensions.

Some critical remarks have to be added concerning the weathering rates for micas. Both minerals, muscovite and biotite, were used as single crystals; scissor-cut pieces, $0.3 \mathrm{~mm}$ thick, were used for the experiments. So approximately 85 percent of the surface consisted of the face (001) only. Because micas in rocks also occur as thin plates, this seems to be justified. In long-time experiments it was observed that both micas show a tendency to split off into very thin plates. This delamination along basal surfaces was much more intensive for biotite already bleached by oxidation of the iron. In such cases the experiment was stopped, and new experiments were started without any agitation of the exchange resin slurry. It has to be admitted that the recorded values for muscovite at $20{ }^{\circ} \mathrm{C}, \mathrm{pH} 5.5$ are close to the border of the limit of detection for such an experimental set-up.

A special experiment was started to test the attack perpendicular to the cleavage face (001) of biotite. A perspex cylinder was pressed via a rubber O-ring against the (001) face of a translucent biotite single crystal by means of an appropriate set-up. This cylinder was filled with slurry of a cation exchange resin in the $\mathrm{H}^{+}$form and kept at $50{ }^{\circ} \mathrm{C}$ for 200 days. The $\mathrm{pH}$ value slowly changed during that time from $\mathrm{pH} 4$ to $\mathrm{pH} 2$ at the end of the experiment. The attack on the biotite crystal is not uniform: different areas are bleached differently, some parts of the crystal show brown spots inside the crystal, which are most probably iron hydroxide. Optical inspections showed etch pits with a diameter of approximately $20 \mu \mathrm{m}$ only in the attacked areas (fig. 3). Sometimes etch channels were visible, leading to brown colored areas inside the crystal. It is assumed this is a result of fission track etching. On their path $\alpha$-particles had transferred the lattice to a metamict state. The sources of the $\alpha$-particles are very small accessory minerals like zircon. Similar etch pits were detected on all biotite (001) surfaces attacked at $\mathrm{pH}$ values of 3.8 and lower during long-term weathering.

Rates with the dimension mass per area and time can be recalculated to the dimension length per time by division by specific gravity (mass per volume); this value reflects the bulk retreat of surface per time. Dissolution rates in $\left[\mu \mathrm{m} \mathrm{a}^{-1}\right]$ are obtained by multiplying the value $\left[\mathrm{mg} \mathrm{m}^{-2} \mathrm{~d}^{-1}\right]$ with the factor $[0.365 /$ specific gravity].

COMPARISON OF RESULTS WITH LITERATURE DATA

All data of this study are based on a geometric measured surface whereas most data in literature were based on a BET surface. A suggestion to calculate the geometric surface of narrow grain sized silt was presented by Murphy (1989). A review of literature by Sverdrup (1990), together with a multitude of his own measurements, included calculations for the ratio BET surface/geometric surface. For this reason table 2 was calculated using Sverdrup's data. The ratio bulk rate of this study/rate literature is in the range of 0.84 to 30 . A probable explanation for this fact is the 


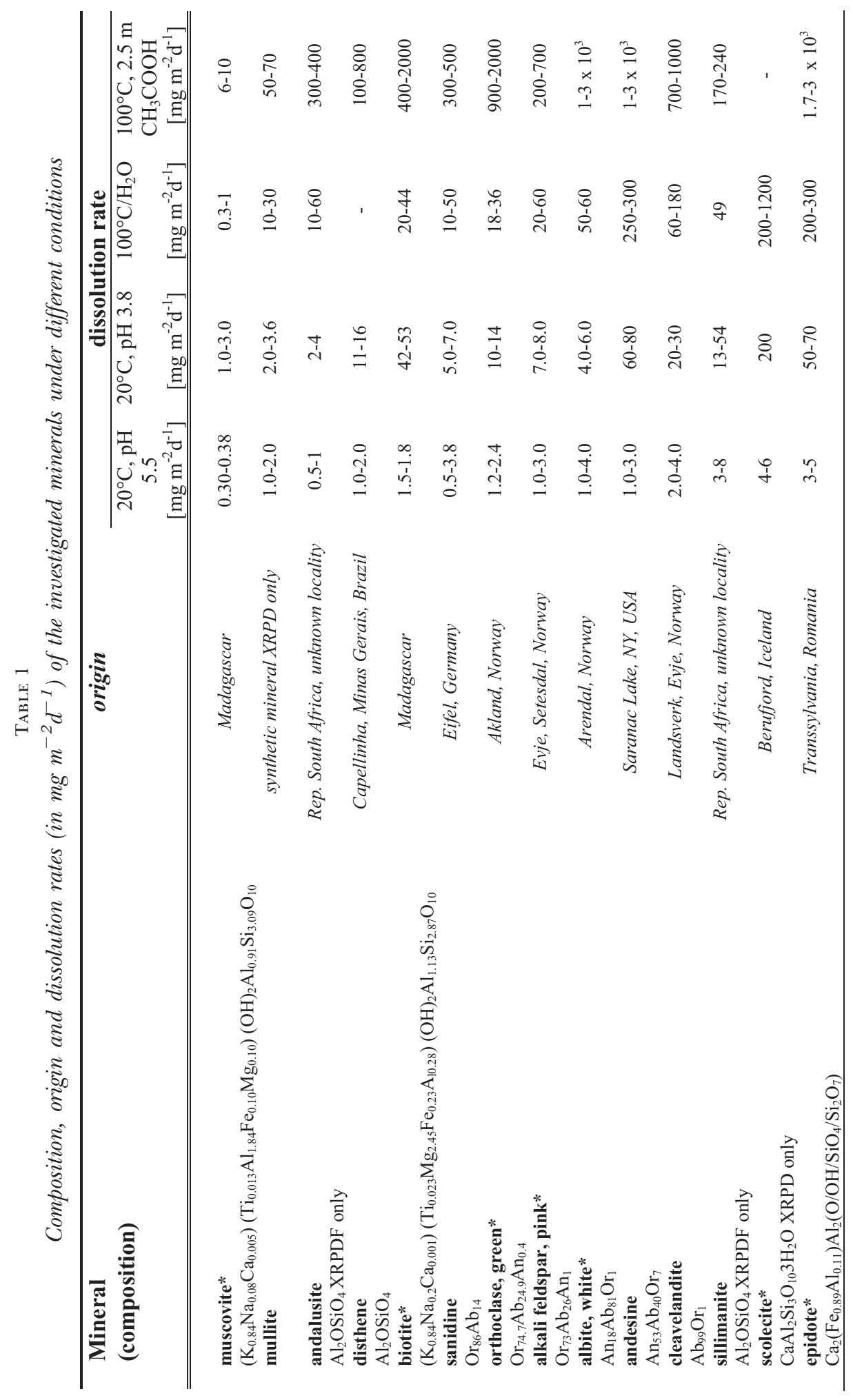




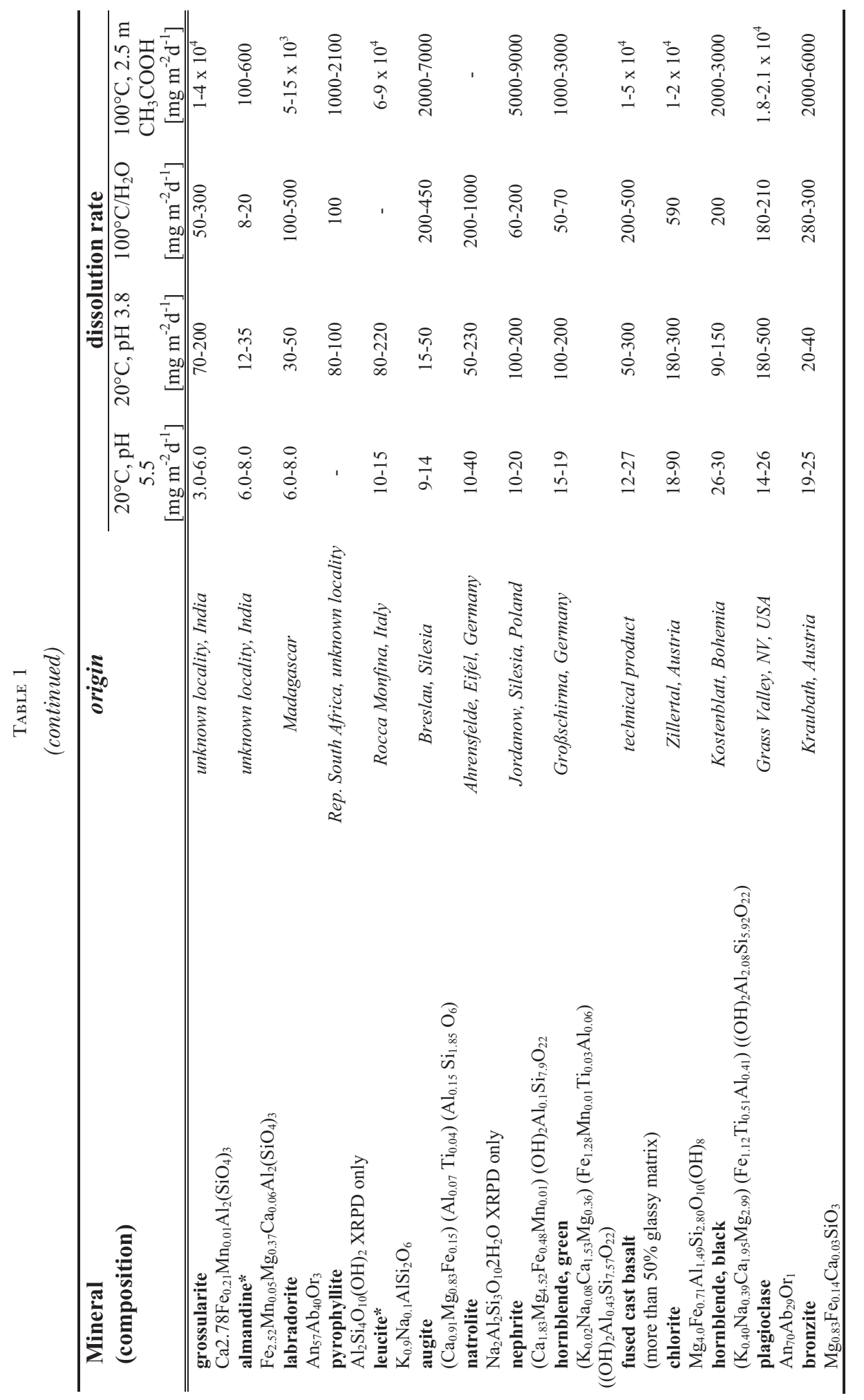




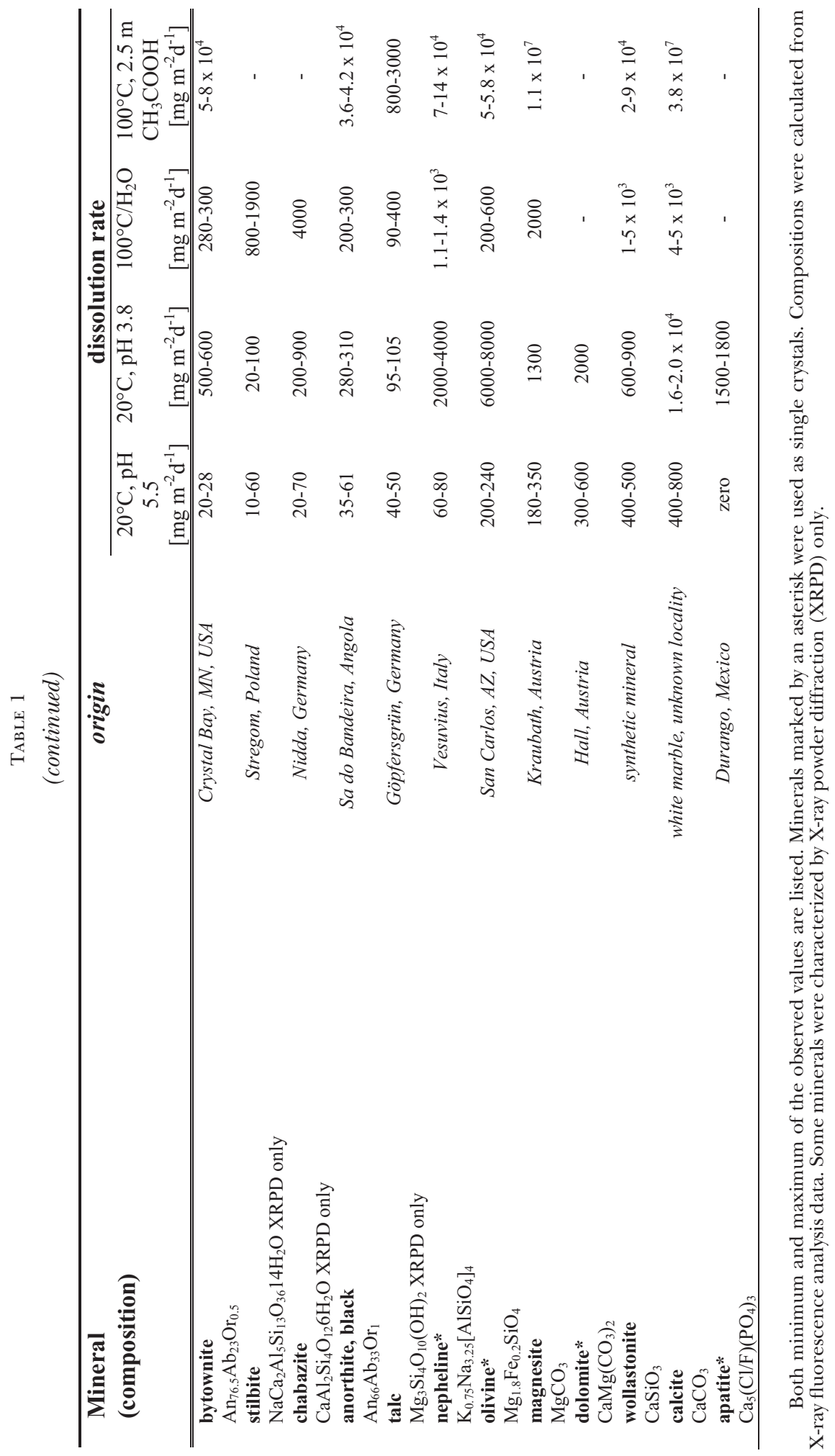




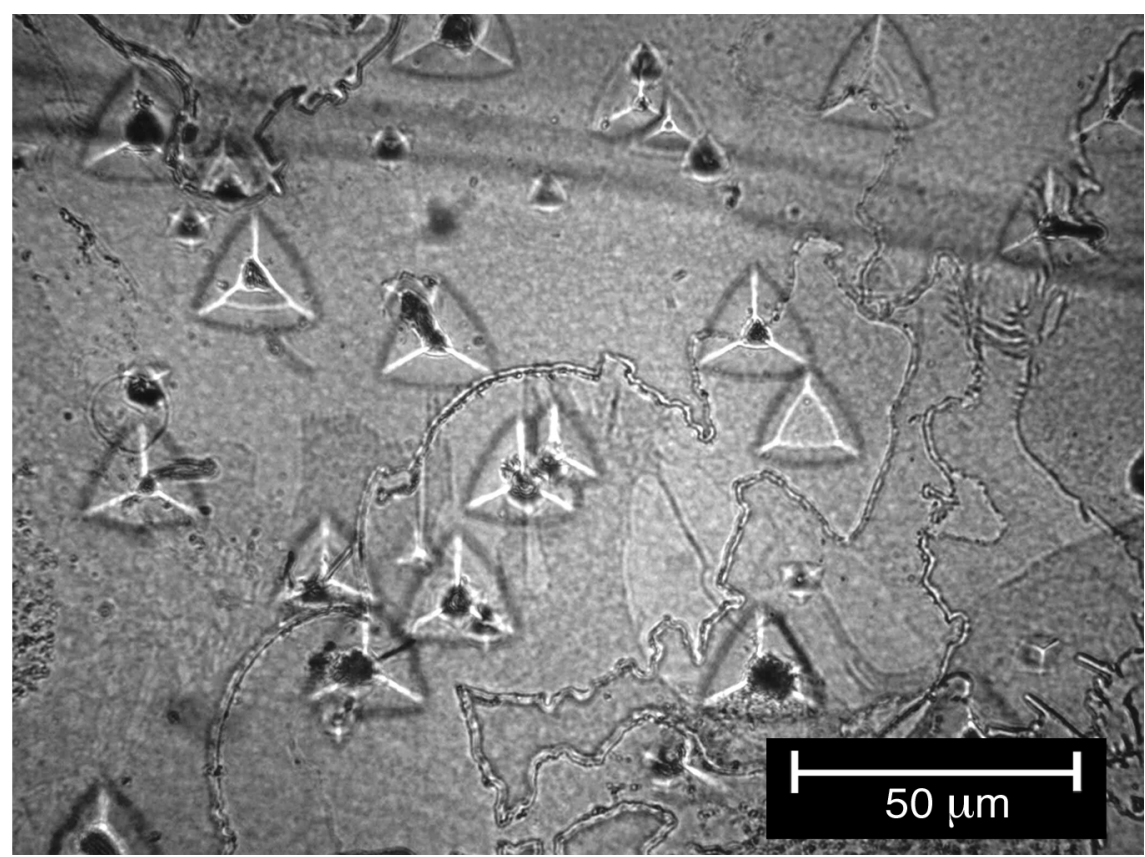

Fig. 3. Etch pits on the attacked area of biotite $\left(50^{\circ} \mathrm{C}, \mathrm{pH} 2\right.$, and $\left.200 \mathrm{~d}\right)$.

extreme undersaturation caused by the ion exchange slurry of this study, but the value may also contain any error arising by the computation of Sverdrup for the ratio $\mathrm{BET} /$ geometric surface. Weathering rates are increased by the use of ion exchange resins; for phlogopite Clemency and Lin (1981) reported an increase of 67 times with respect to an experimental arrangement without exchange resin but a similar $\mathrm{pH}$ value. It should be stressed that the ratio for nepheline is 1.3 , and the rate for nepheline used for comparison was measured using single crystal disks with a geometric measured surface by Tole and others (1986).

In-situ measurements by phase shift interferometry by Satoh and others (2007) showed a bulk retreat of surface of $1.4 \times 10^{-5} \mathrm{~nm} \mathrm{sec}^{-1}$ for an anorthite $\mathrm{An}_{96} \mathrm{Ab}_{4}$ at near neutral $\mathrm{pH}, 22^{\circ} \mathrm{C}$; this applies to $4.4 \mu \mathrm{m} \mathrm{a} \mathrm{a}^{-1}$. The bulk value for a plagioclase $\mathrm{An}_{66} \mathrm{Ab}_{33} \mathrm{Or}_{1}$ at $20^{\circ} \mathrm{C}$, pH 5.5 of this study was $4.8 \mu \mathrm{m} \mathrm{a} \mathrm{a}^{-1}$. According to Sverdrup (1990) anorthite dissolution rates show a flat plateau in the $\mathrm{pH}$ range 8 to 6 , thus the corroboration seems quite sufficient.

The range of dissolution rates for calcite at $\mathrm{pH} 5.5,20^{\circ} \mathrm{C}$ of this study were recalculated to the dimension $\mathrm{mmol} \mathrm{cm}^{-2} \mathrm{sec}^{-1}$. They agree completely with the values observed by Plummer and others (1978) by pH stat and free drift experiments. Reliable experimental data for rock corrosion above ground in nature are available only for limestone. In 1999 Urushibara-Yoshino and others published an experimental report on limestone corrosion in Japan. They used limestone specimens of different origin ground to spherical tablets which were exposed to weathering $1.5 \mathrm{~m}$ above the ground for 5 years. Annual weight losses were reported for two years with extreme climate conditions, one with a very wet and cool summer, the other with an exceptionally dry and hot summer, and for three different locations at approximately $44^{\circ} \mathrm{N}$, $31^{\circ} \mathrm{N}$, and $26^{\circ} \mathrm{N}$ latitude, respectively. Moses (1996) and Jaynes and Cooke (1987) investigated limestone corrosion in Northern Ireland and London. For two years, they 


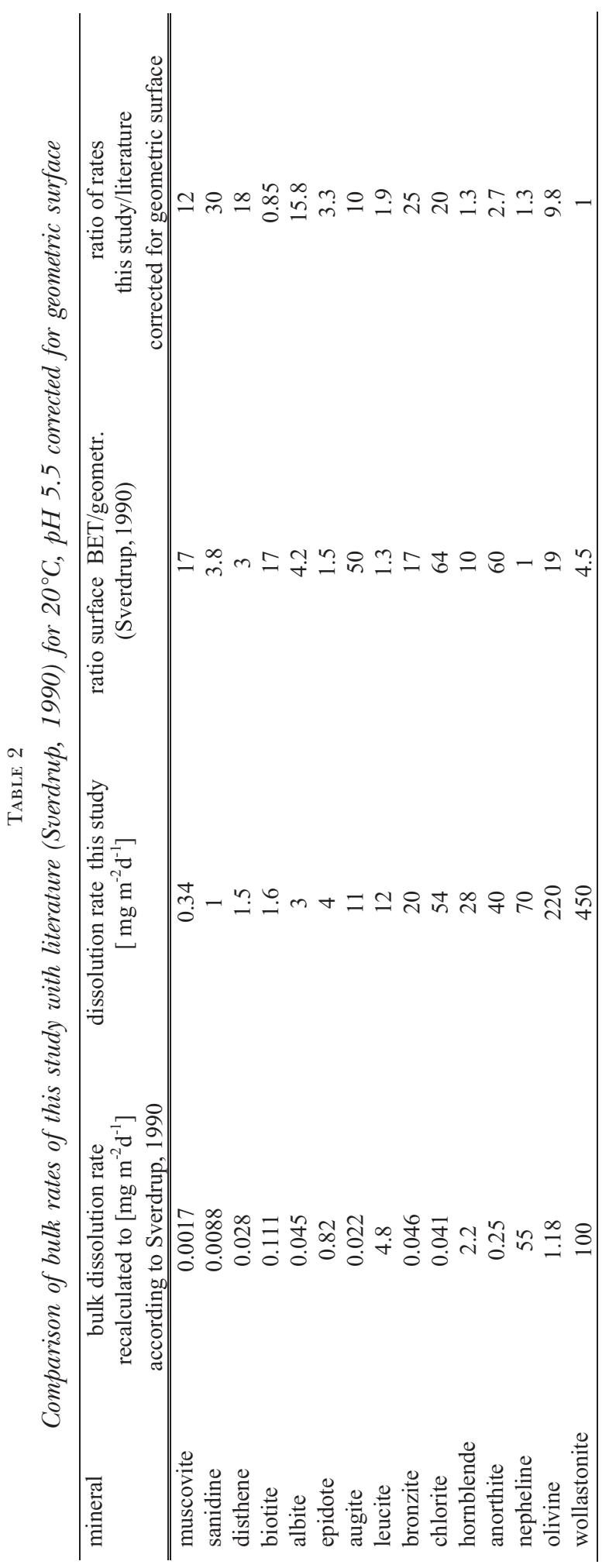


exposed limestone tablets fixed to a wind-blown carousel in open rural and urban environments. Calculations based on published data for the five locations yielded rates of solution in the range of 10 percent to 38 percent of that obtained for the condition $20{ }^{\circ} \mathrm{C}, \mathrm{pH} 5.5$ in this study. This is in fair agreement with a geomorphologic field study. Bauer (1964) measured the denudation rate for bare limestone sealed off from soil and vegetation influence in the Austrian Alps; he arrived at rates in the range 7 to 12 $\mu \mathrm{m} \mathrm{a}^{-1}$, the bulk rate of this study $20^{\circ} \mathrm{C}, \mathrm{pH} 5.5$ applies to $80 \mu \mathrm{m} \mathrm{a} \mathrm{a}^{-1}$.

Any attempt to draw a conclusion from these data should bear in mind that calcite weathering is quite different from silicate weathering:

- Calcite dissolution is reversible when water is evaporated.

- Calcite dissolution at a constant carbon dioxide partial pressure is facilitated by low temperature (Miller, 1952; Plummer and Busenberg, 1982).

- Calcite dissolution is not influenced by very low concentrations of foreign cations.

On the rough assumption that the effects of evaporation and temperature offset each other for calcite, a wetting time in the range between 10 percent and 40 percent can be presumed for the field reports from Japan and the United Kingdom that represent weathering in a temperate humid climate.

\section{REASONING FOR TEST CONDITIONS}

The surfaces of monuments or walls of buildings are wetted with air-saturated water by rain, dew or fog; without any air pollution a $\mathrm{pH}$ value of 5.5 can be assumed. Water films adhering to wetted, flat, inclined surfaces normally have a thickness of approximately $25 \mu \mathrm{m}$ (Franke and Mircea, 2005) after the end of a rain shower. Already Sereda (1974) found by experiments that a relative humidity of more than 80 percent caused an extremely thin water film on a solid surface, which is sufficient to trigger reactions between water and solid. At 99 percent relative humidity such a layer may reach $1 \mu \mathrm{m}$ thickness; fog or dew causes layers in the range of $10 \mu \mathrm{m}$ (Fitzgerald and others, 1998). Such thin layers of water have a high ratio of surface versus mass of water in the 1 to $0.1 \mathrm{~m}^{2} \mathrm{~g}^{-1}$ range. In accordance with Henry's law such thin water layers are quickly equilibrated with the carbon dioxide content of air. Therefore the data for $20^{\circ} \mathrm{C}, \mathrm{pH} 5.5$ represent a maximum rate of estimated natural weathering on the assumption that rocks above ground are permanently wetted by thin water films, which are renewed by intermittent rain, fog or dew. Admittedly, the term "maximum rate of estimated natural weathering" applies only to an abiotic water-mineral interaction. In reality any permanently wetted surface would be colonized by micro organisms. Biofilms and biocrusts are generally suspected to cause higher weathering rates due to biodegradation (Warscheid and Braams, 2000). Only rarely was a protective effect reported (Camuffo, 1996).

Table 3 shows the bulk dissolution rates of the most important rock-forming minerals. Bulk rates were calculated using the mean values of maximum and minimum rates from table 1 . For a better overview only four groups of feldspars are noted: Ca plagioclase $=A n$ is higher than $A n_{65}$, medium plagioclase $=A_{60} A_{b} b_{40}$ to $A n_{50} A b_{50}$, and $\mathrm{Na}$ plagioclase $=\mathrm{Ab}$ is higher than $\mathrm{Ab}_{50}$. Alkali feldspar characterizes feldspar with $\mathrm{Or}_{70}$ or higher. Also pyroxene and hornblende are noted as groups only. The values in table 3 indicate that only the condition $100^{\circ} \mathrm{C}, 2.5 \mathrm{~m} \mathrm{CH}_{3} \mathrm{COOH}$ will be apt for the intended test. The acceleration of weathering achieved by the test is expressed by the ratio of the dissolution rates. This ratio is in the range $3-7 \times 10^{4}$ for carbonates, in the range $1-7 \times 10^{3}$ for feldspathoids and zeolites, and in the range $2.5-15 \times 10^{2}$ for most rock-forming silicates. There are only two exceptions; hornblende shows a ratio of 100 and muscovite only 24 . In figure 4 the rate of dissolution of minerals at $20^{\circ}$, $\mathrm{pH} 5.5$ is plotted against the experimental condition $100{ }^{\circ} \mathrm{C}, 2.5 \mathrm{~m} \mathrm{CH}_{3} \mathrm{COOH}$. With a 
TABLE 3

Bulk dissolution rates of important rock forming minerals

\begin{tabular}{lcccc}
\hline Mineral & $\begin{array}{c}20^{\circ} \mathrm{C}, \mathrm{pH} 5.5 \\
{\left[\mathrm{mg} \mathrm{m}^{-2} \mathrm{~d}^{-1}\right]}\end{array}$ & $\begin{array}{c}20^{\circ} \mathrm{C}, \mathrm{pH} 3.8 \\
{\left[\mathrm{mg} \mathrm{m}^{-2} \mathrm{~d}^{-1}\right]}\end{array}$ & $\begin{array}{c}100^{\circ} \mathrm{C}^{-2} \mathrm{H}_{2} \mathrm{O} \\
{\left[\mathrm{mg} \mathrm{m}^{-2} \mathrm{~d}^{-1}\right]}\end{array}$ & $\begin{array}{c}100^{\circ} \mathrm{C}, 2.5 \mathrm{M} \mathrm{CH}_{3} \mathrm{COOH} \\
{\left[\mathrm{m} \mathrm{m}^{-2} \mathrm{~d}^{-1}\right]}\end{array}$ \\
\hline \hline muscovite & 0.34 & 2.0 & 0.65 & 8.0 \\
biotite & 1.60 & 48 & 32 & 1000 \\
alkali feldspar & 2.10 & 10.5 & 35 & 800 \\
Na plagioclase & 2.50 & 17 & 60 & 1500 \\
epidote & 4.00 & 60 & 250 & 2000 \\
medium plagioclase & 7.00 & 40 & 300 & 10000 \\
leucite & 12.00 & 150 & - & 75000 \\
pyroxene & 17.00 & 33 & 325 & 4500 \\
hornblende & 25.00 & 145 & 125 & 2500 \\
Ca plagioclase & 40.00 & 300 & 300 & 40000 \\
chlorite & 54.00 & 240 & 590 & 15000 \\
nepheline & 70.00 & 3000 & 1250 & $10^{5}$ \\
olivine & 220.00 & 7000 & 400 & $5.6 \times 10^{4}$ \\
magnesite & 285.00 & 1300 & 2000 & $1 \times 10^{7}$ \\
calcite & 600.00 & $1.8 \times 10^{4}$ & $4.5 \times 10^{3}$ & $3.8 \times 10^{7}$ \\
\hline
\end{tabular}

alkali feldspar $=$ more than Or70 $/$ Na plagioclase $=$ more than Ab50 medium plagioclase $=$ An50-An $65 /$ Ca plagioclase $=$ more than An65

few variations, acceleration increases with increasing weathering rate, including the carbonates. In figure 4 the horizontal distance between the dotted line and the descriptive point for any mineral or mineral group represents the ratio bulk rate $100^{\circ} \mathrm{C}, 2.5 \mathrm{~m} \mathrm{CH} 3 \mathrm{COOH} / 20^{\circ} \mathrm{C}, \mathrm{pH} 5.5$, due to the logarithmic axis.

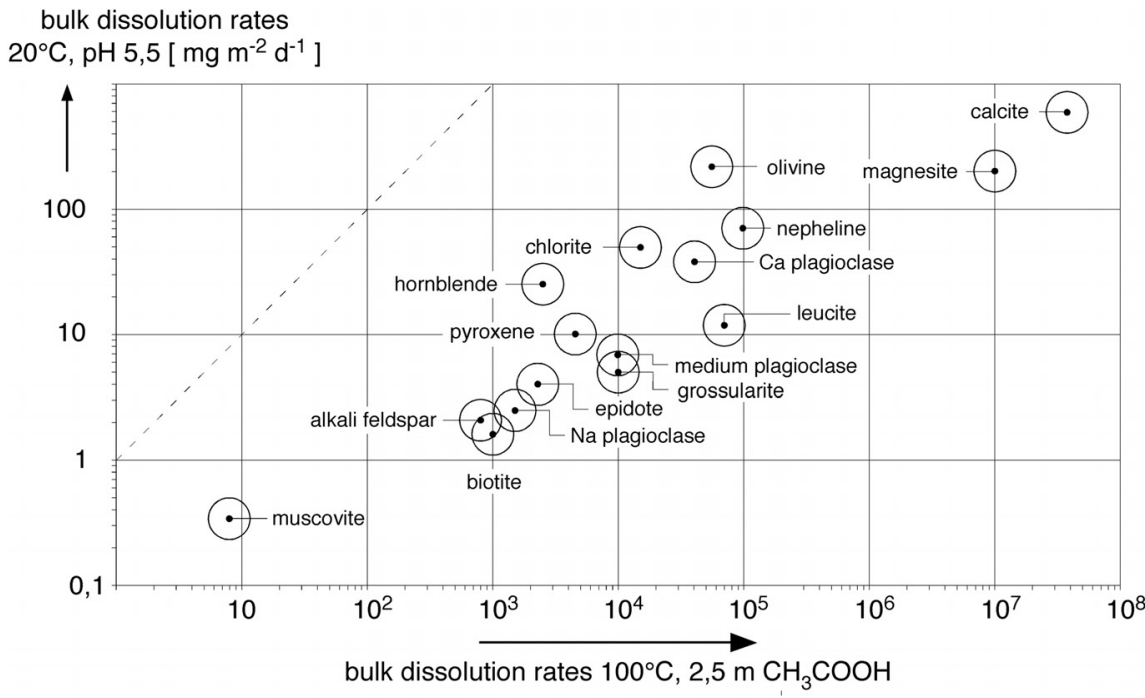

The horizontal distance between the dotted line and the descriptive point represents the ratio of the bulk rate $100^{\circ} \mathrm{C}, 2.5 \mathrm{~m} \mathrm{CH}_{3} \mathrm{COOH} / 20^{\circ} \mathrm{C}, \mathrm{pH} 5.5$.

Fig. 4. Bulk rates of dissolution at $20^{\circ} \mathrm{C}$, pH 5.5 versus $100^{\circ} \mathrm{C}, 2.5 \mathrm{~m} \mathrm{CH}_{3} \mathrm{COOH}$. 
TABLE 4

Dissolution rate of different rocks at $100^{\circ} \mathrm{C}, 2.5 \mathrm{M} \mathrm{CH} 3 \mathrm{COOH}$

\begin{tabular}{|c|c|c|}
\hline Rock & $\mathrm{mg} \mathrm{m}^{-2} \mathrm{~d}^{-1}$ & Composition \\
\hline granite I & 550 & qz., Na plg., alk.-fsp., biot. \\
\hline leucogranite & 1900 & qz., alk.-fsp., few Ca.plg., few biot. \\
\hline schist I & 2150 & qz., musc., biot., chloritoid \\
\hline gneiss I & 2400 & qz., alk.-fsp., biot., few Na-plg. + hbl. \\
\hline schist III & 2900 & qz., musc.,chlorite, chloritoid \\
\hline leucosyenite & 3000 & qz., microcline, few Na-plg. \\
\hline gneiss II & 3450 & Na-plg., biot., hbl., few qz. \\
\hline brick III, brown & 3600 & qz., alk-fsp., fired clay, $15 \%$ open porosity \\
\hline eklogite & 4400 & cl.-prx (omphacite), garnet, disthene, rutile \\
\hline brick II, red & 4600 & qz., hematite, fired clay, $16 \%$ open porosity \\
\hline granite II & 5000 & $\begin{array}{l}\text { qz., alk-fsp. (alterated), biot. partly altered to chlorite } \\
\text { and epidote, Na-plg. altered to sericite }\end{array}$ \\
\hline schist II & 5050 & musc., biot., qz. \\
\hline dolerite & 5150 & ophitic texture of plg., cl.-prx., apatite \\
\hline gabbro I & 6600 & Ca-plg., prx., phlogopite, magnetite, olv., apatite \\
\hline black schist & 8400 & qz., biot., musc., chamosite \\
\hline fused cast basalt & 12000 & more than $50 \%$ brown glass, + olv., prx., vesicles \\
\hline gabbro II & 12100 & medium-plg., clino-prx., few qz., biot., apatite \\
\hline gabbro III & 17800 & medium-plg., ortho-prx., clino-prx., olv., biot., chlorite \\
\hline basalt lava & 18000 & Ca- plg., prx., olv., vesicles \\
\hline gabbro IV & 25200 & medium-plg., prx., hbl., biot., ore \\
\hline nephelinite & 25200 & neph., prx., olv. with serpent. , few calcite, glass \\
\hline olivine balsalt & 30000 & Ca-plg., prx., olv., magnetite \\
\hline nepheline syenite I & 55600 & neph., Na-plg., arfvedsonite, aegirinaugite \\
\hline nepheline syenite II & 62400 & neph., Na-plg., arfvedsonite, aegirinaugite \\
\hline brick I, yellow & 107400 & qz., rankinite, fired clay, $6 \%$ open porosity \\
\hline nepheline syenite III & 163400 & alk-fsp., albite, neph., aegirinaugite, leucite \\
\hline syenite & 211000 & microcline, qz., biot., prx., calcite + apatite \\
\hline serpentine & 831000 & lizardite + calcite \\
\hline synthetic sandstone & $1.5 \times 10^{6}$ & qz., calcite, traces of a CSH phase, $26 \%$ open porosity \\
\hline concrete & $2.5 \times 10^{6}$ & quartz gravel, afwillite, calcite, $6 \%$ open porosity \\
\hline red sandstone & $2.8 \times 10^{7}$ & qz., calcite, hematite, $0.5 \%$ open porosity \\
\hline white marble & $3.8 \times 10^{7}$ & calcite \\
\hline
\end{tabular}

Abbreviations:

alk-fsp. = alkali feldspar with more than Or70 / biot. = biotite $/$ musc. $=$ muscovite

Ca-plg. $=$ plagioclase with more than An65 / medium-plg $=$ An50-An65

Na-plg. = plagioclase with more than Ab50 / hbl. = hornblende $/$ neph. $=$ nepheline $/$ olv. $=$ olivine

prx. = pyroxene $/$ serpent. $=$ serpentinization $/$ qz. $=$ quartz

Thirty-two different rocks and bricks were used for a comparative weathering test; results are shown in table 4 . Again, the rocks were cut into rectangular specimens, with a surface in the range of 10 to $20 \mathrm{~cm}^{2}$. Most rocks were supplied by firms specializing in the supply of facade plates, floor tiles and tombstones. Very often the product names were not correct; therefore the names and descriptions of the rocks in table 4 are based on the inspection of thin sections. Weathering rates of rocks range over some powers of ten; therefore the testing time has to be adapted with respect to the susceptibility of 
the specimen towards weathering. The first minutes of the rock weathering test should be watched by ocular inspection, any lasting effervescence points to the presence of carbonates. In such cases the testing time should be restricted to 30 minutes or less. Any test has to be stopped if optical inspection shows grains are chipping off from the surface of the specimen. Each specimen has to be dried at $120^{\circ} \mathrm{C}$ till a constant weight is achieved. Long drying times are necessary especially for sediments and artificial stones with considerable open porosity.

\section{DISCUSSIONS}

A quick test for the resistance of building materials towards chemical weathering has been suggested: treatment with boiling $2.5 \mathrm{~m}$ acetic acid in a Soxhlet extractor. Results for 32 selected rocks and man-made bricks are shown in table 4. Rates are listed as mass loss per area and time, low rates indicating high durability. Rates listed in table 4 range over nearly five powers of ten. Acceleration of weathering is dependent mainly on the most weathering-prone mineral present in the specimen. Indeed the rank of durability mainly reflects the expectations with respect to the mineral composition of natural rocks, but the variations of rate within similar rock types are very high. The quotient highest rate/lowest rate of a rock type can be used as an indicator. Such quotients calculated from table 4 reach a value of 10 for granites and 6 for rocks with basaltic compositions. No analcite-bearing basalt has been tested; such basalts are known owing to their high weathering rates. Extremely high variations of weathering rates were observed especially for man-made bricks and for rocks containing calcite. It has to be stressed that the test is designed to predict the durability of stones above ground; its use for estimating stone decay under subsoil conditions may be limited. Soil is a microbial microcosm; bacteria, fungi, and other organisms can create acids, chelating agents, carbon dioxide, and may cause anoxic conditions.

For biotite a special experiment showed that etch pits with protruding etch channels were formed on the basal face in acid environments (fig. 3); this effect is most probably due to fission track etching. In thin section inspections isotropic halos are well known to be ubiquitous in biotite of magmatic origin; they are caused by accessory minute zircon or monazite crystals bearing U or Th. That means bulk weathering rates of biotites of magmatic origin may be considerably dependent on radiation damage.

In the end, the question remains: is the mechanism of natural weathering different from the mechanism used for the rock weathering test? The answer is yes from a theoretical point of view due to the step wave model of Lasaga and Lüttge (2001); natural weathering is presumed to occur at low undersaturation, whereas the condition $100^{\circ} \mathrm{C}, \mathrm{pH} 2.3$ surely applies to high undersaturation. This fact was corroborated by a special experiment.

The mechanism of dissolution of a crystal in a liquid involves several steps, one of which is the rate of breaking bonds at the surface of the crystal; at least two other steps are controlled by diffusion. According to the convoy principle the rate of the slowest step determines the overall rate. A dissolving single crystal sphere turns its shape into a crystal with curved faces only if the bond-breaking step is the slowest one. This holds true even if a solid reaction product of the dissolution adheres as a porous layer at the surface of the sphere (Franke and Heimann, 1970). A molecular-kinetic theory of single crystal sphere dissolution was proposed by Lacmann and others (1974a, 1974b). The olivine used in this study was of gem quality; it was partly ground to polished spheres of $4 \mathrm{~mm}$ diameter and etched under all conditions of this study. Only under the condition $100{ }^{\circ} \mathrm{C}, 2.5 \mathrm{~m} \mathrm{CH}_{3} \mathrm{COOH}$ did the sphere change its shape to an orthorhombic pyramid (fig. 5). Under all other conditions the spheres remained spherical, even at $100{ }^{\circ} \mathrm{C}, \mathrm{pH} 4$. This means that the natural weathering rate of olivine does not depend on the crystal lattice orientation of the attacked surface. Analogue experiments with other minerals were not possible; a mass loss of at least 15 percent is 


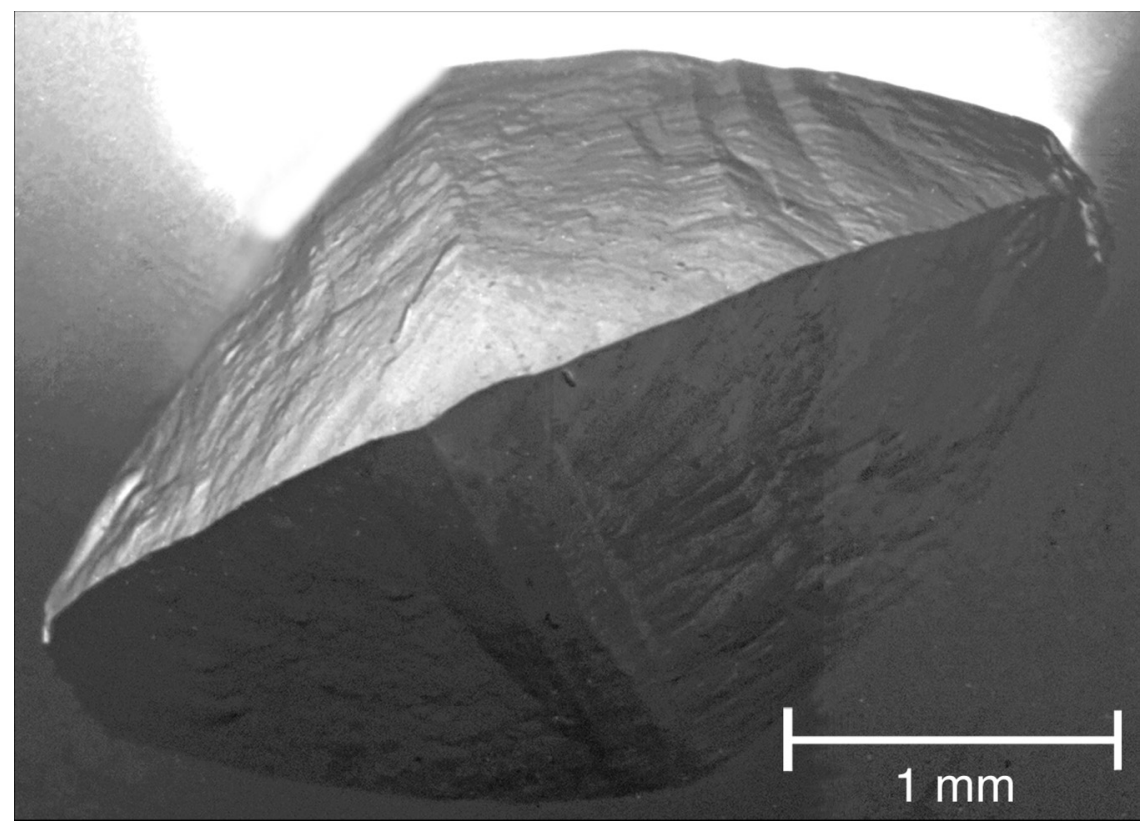

Fig. 5. SEM picture of an olivine sphere dissolved at $100^{\circ} \mathrm{C}, \mathrm{pH} 2.3$.

needed (Khokhryakov and Palyanov, 2007), and the rates for most minerals would be much too small to yield a result in acceptable time. Moreover, the crystal spheres should not contain exsolutions or show polysynthetic twinning.

\section{ACKNOWLEDGMENTS}

Thanks are due to Eveline Siegmann for her able technical assistance and to the helping hands of Eva Logemann (figures and tables), Christiane Behr (thin sections), Anne Beck (English style), Wolfgang Bruns (literature research) and Ralf Milke (microprobe). Special thanks go to Prof. Dr. Rainer Abart who gave me the opportunity to continue experimental work after my retirement. This paper was much improved by suggestions of Andreas Lüttge and critical remarks of two anonymous referees.

\section{REFERENCES}

Aagaard, P., and Helgeson, H. C., 1982, Thermodynamic and kinetic constraints on reaction rates among minerals and aqueous solutions. I. Theoretical considerations: American Journal of Science, v. 282, p. 273-285.

Arvidson, R. S., Beig, M. S., and Lüttge, A., 2004, Single-crystal plagioclase feldspar dissolution rates measured by vertical scanning interferometry: American Mineralogist, v. 89, p. 51-56.

Bauer, F., 1964, Kalkabtragungsmessungen in den Österreichischen Kalkhochalpen: Erdkunde, v. 18, p. 95-102, doi:10.3112/erdkunde.1964.02.04.

Benavente, D., Cultrone, G., and Gomez-Heras, M., 2008, The combined influence of mineralogical, hygric and thermal properties on the durability of porous building stones: European Journal of Mineralogy, v. 20, p. 673-685, doi:10.1127/0935-1221/2008/0020-1850.

Bennett, P. C., Melcer, M. E., Siegel, D. I., and Hassett, J. P., 1988, The dissolution of quartz in dilute aqueous solutions of organic acids at $25^{\circ} \mathrm{C}$ : Geochimica et Cosmochimica Acta, v. 52, p. 1,521-1,530, doi:10.1016/ 0016-7037(88)90222-0.

Berner, R. A., and Holdren, G. R., Jr., 1979, Mechanism of feldspar weathering. II. Observations of feldspars from soils: Geochimica et Cosmochimica Acta, v. 43, p. 1,173-1,186, doi:10.1016/0016-7037 (79)90110-8.

Brantley, S. L., and Chen, Y., 1995, Chemical weathering rates of pyroxenes and amphiboles, in White, A. F., 
and Brantley, S. L., editors, Chemical weathering rates of silicate minerals: Reviews in Mineralogy, v. 31, p. $119-172$.

Brunauer, S., Emmet, P. H., and Teller, E., 1938, Adsorption of gases in multimolecular layers: Journal of the American Chemical Society, v. 60, p. 309-319, doi:10.1021/ja01269a023.

Butenuth, Ch., 2001, Strength and weathering of rock as boundary problems: London, Imperial College Press, $270 \mathrm{p}$.

Cabrera, N., 1960, Kinematic theory of crystal dissolution and its application to etching, in DeBoer, J. H., editor, Reactivity of Solids: Amsterdam, 1960, Proceedings of the International Symposium on Reactivity of Solids, 4, p. 345-351.

Camuffo, D., 1997, Perspectives on risks to architectural heritage, in Baer, N. S., and Snethlage, R., editors, Saving our architectural heritage-The conservation of historic stone structures: Berlin, March 3-8, 1996, Report of the Dahlem Workshop on Saving Our Architectural Heritage: Chichester, John Wiley \& Sons, p. 69.

Clemency, C. V., and Lin, F.-C., 1981, Dissolution kinetics of phlogopite: II. Open system using an ion exchange resin: Clays and Clay Minerals, v. 29, p. 107-112, doi:10.1346/CCMN.1981.0290204.

Correns, C. W., and von Engelhardt, W., 1939, Neue Untersuchungen über die Verwitterung des Kalifeldspats: Chemie der Erde, v. 12, p. 1-22.

Fenter, P., Cheng, I., Zhang, Z., Krekeler, M. P. S., and Sturchio, N. C., 2003, Orthoclase dissolution kinetics probed by in-situ X-ray reflectivity: Effects of temperature, $\mathrm{pH}$, and crystal orientation: Geochimica et Cosmochimica Acta, v. 67, p. 197-211, doi:10.1016/S0016-7037(02)01084-0.

Ferrow, E. A., Kalinowski, B. E., Veblen, D. R., and Schweda, P., 1999, Alteration products of experimentally weathered biotite studied by high-resolution TEM and Mössbauer spectroscopy: European Journal of Mineralogy, v. 11, p. 999-1,010.

Fitzgerald, K. P., Nairn, J., and Atrens, A., 1998, The chemistry of copper patination: Corrosion Science, v. 40, n. 12, p. 2,029-2,050, doi:10.1016/S0010-938X(98)00093-6.

Frank, F. C., 1958, On the kinematic theory of crystal growth and dissolution Processes, in Doremus, R. H., Roberts, B. W., and Turnbull, D., Growth and perfection of crystals: New York, John Wiley \& Sons, p. 411-419.

Franke, W., and Heimann, R., 1970, Hydrothermal dissolution reactions of magnesium-aluminium-spinel in alkaline solutions: Journal of Crystal Growth, v. 7, p. 97-101, doi:10.1016/0022-0248(70)90121-1.

Franke, W. A., and Mircea, M., 2005, Plutarch's report on the blue patina of bronze statues at Delphi: A scientific explanation: Journal of the American Institute of Conservation, v. 44, p. 103-116.

Franke, W. A., and Teschner-Steinhardt, R., 1994, An experimental approach to the sequence of stability of rock-forming minerals towards chemical weathering: Catena, v. 21, p. 279-290, doi:10.1016/03418162(94)90018-3.

Franklin, J. A., and Chandra, R., 1972, The slake durability test: International Journal of Rock Mechanics and Mining Science, v. 9, p. 325-341.

Gupta, A. S., and Rao, K. S., 2001, Weathering indices and their applicability for crystalline rocks: Bulletin of Engineering Geology and the Environment, v. 60, n. 3, p. 201-222, doi 10.1007/s100640100113.

Harned, H. S., and Ehlers, R. W., 1933, The dissociation constant of acetic acid from 0 to $60^{\circ} \mathrm{C}$ centigrade: Journal of the American Chemical Society, v. 55, p. 652-656, doi: 10.1021/ja01329a027.

Heimann, R. B., 1975, Auflösung von Kristallen-Theorie und technische Anwendung, Applied Mineralogy, v. 8: Wien, New York, Springer-Verlag, $270 \mathrm{p}$.

Hellmann, R., 1994, The albite-water system: Part I. The kinetics of dissolution as a function of $\mathrm{pH}$ at 100, 200, and $300^{\circ} \mathrm{C}$ : Geochimica et Cosmochimica Acta, v. 58, p. 595-611, doi:10.1016/00167037(94)90491-X.

_ 1995, The albite-water system: Part II. The time-evolution of the stoichiometry of dissolution as a function of $\mathrm{pH}$ at 100,200 , and $300^{\circ} \mathrm{C}$ : Geochimica et Cosmochimica Acta, v. 59, n. 9, p. 1,669-1,697, doi:10.1016/0016-7037(95)00075-B.

Hellmann, R., Egglestone, C. M., Hochelle, M. F., Jr., and Crerar, D. A., 1990, The formation of leached layers on albite surfaces during dissolution under hydrothermal conditions: Geochimica et Cosmochimica Acta, v. 54, p. 1,267-1,281, doi:10.1016/0016-7037(90)90152-B.

Hurd, C. B., and Marotta, A. J., 1940, The time of set of acidic and basic mixtures containing phosphoric acid: Journal of the American Chemical Society, v. 62, p. 2,767-2,770, doi: 10.1021/ja01867a045.

Inskeep, W. P., Nater, E. A., Bloom, P. R., Vandervoort, D. S., and Erich, M. S., 1991, Characterization of laboratory weathered labradorite surfaces using X-ray photoelectron spectroscopy and transmission electron microscopy: Geochimica et Cosmochimica Acta, v. 55, p. 787-800, doi:10.1016/00167037(91)90342-3.

Jayawardena, U. de S., and Izawa, E., 1994, A new chemical index of weathering for metamorphic silicate rocks in tropical regions: A study from Sri Lanka: Engineering Geology, v. 36 p. 303-310, doi:10.1016/ 0013-7952(94)90011-6.

Jaynes, S. M., and Cooke, R. U., 1987, Stone weathering in southeast England: Atmospheric Environment, v. 21, p. 1,601-1,622, doi:10.1016/0004-6981(87)90321-0.

Jeong, G. Y., and Kim, H. B., 2003, Mineralogy, chemistry and formation of oxidized biotite in the weathering profile of granitic rocks: American Mineralogist, v. 88, p. 352-364.

Jordan, G., Higgins, S. R., Egglestone, C. M., Swapp, S. M., Janney, D. E., and Knauss, K. G., 1999, Acidic dissolution of plagioclase: In-situ observations by hydrothermal atomic force microscopy: Geochimica et Cosmochimica Acta, v. 63, p. 3,183-3,191, doi:10.1016/S0016-7037(99)00225-2.

Kalinowski, B. E., and Schweda, P., 1996, Kinetics of muscovite, phlogopite, and biotite dissolution and alteration at $\mathrm{pH}$ 1-4, room temperature: Geochimica et Cosmochimica Acta, v. 60, p. 367-385, doi:10.1016/0016-7037(95)00411-4

Khokhryakov, A. F., and Pal'yanov, Y. N., 2007, The evolution of diamond morphology in the process of 
dissolution: Experimental data: American Mineralogist, v. 92, p. 909-917, doi: 10.2138/ am.2007.2342.

Kinrade, S. D., Del Nin, J. W., Schach, A. S., Stone, T. A., Wilson, K. L., and Knight, C. G., 1999, Stable fiveand six-coordinated silicate anions in aqueous solution: Science, v. 285, p. 1,542-1,545, doi: 10.1126 / science.285.5433.1542.

Knight, T. G., Balec, R. J., and Kinrade, S. D., 2007, The structure of silicate anions in aqueous alkaline solutions: Angewandte Chemie, v. 119, p. 8,296-8,300, doi: 10.1002/ange.200702986.

Lacmann, R., Franke, W., and Heimann, R., 1974a, The dissolution forms of single crystal spheres. I. Theory for the molecular-kinetic interpretation: Journal of Crystal Growth, v. 26, p. 107-116, doi:10.1016/00220248(74)90208-5.

Lacmann, R., Heimann, R., and Franke, W., 1974b, The dissolution forms of single crystal spheres: II. Theory for the molecular-kinetics interpretation: Journal of Crystal Growth, v. 26, p. 117-121, doi:10.1016/00220248(74)90209-7.

Lasaga, A. C., and Lüttge, A., 2001, Variation of crystal dissolution rate based on a dissolution stepwave model: Science, v. 291, p. 2,400-2,404, doi: 10.1126/science.1058173.

Lee, M. R., Brown, D. J., Smith, C. L., Hodson, M. E., Mackenzie, M., and Hellmann, R., 2007, Characterization of mineral surfaces using FIB and TEM: A case study of naturally weathered alkali feldspars: American Mineralogist, v. 92, p. 1,383-1,394, doi: 10.2138/am.2007.2453.

Lüttge, A., Bolton, E. W., and Lasaga, A. C., 1999, An interferometric study of the dissolution kinetics of anorthite: The role of reactive surface area: American Journal of Science, v. 299, p. 652-678.

Miller, J. P., 1952, A portion of the system calcium carbonate-carbon dioxide-water, with geological implications: American Journal of Science, v. 250, p. 161-203.

Moses, C. A., 1996, Methods for investigating stone decay mechanisms in polluted and 'clean' environments, North Ireland, in Smith, B. J., and Worke, P. A., editors, Processes of Urban Stone decay: Shaftesbury, United Kingdom, Donhead Publishing Ltd., p. 212-227.

Murphy, W. M., 1989, Dislocations and feldspar dissolution: European Journal of Mineralogy, v. 1, p. 315326.

Oelkers, E. H., 2001, General kinetic description of multioxide silicate mineral and glass Dissolution: Geochimica et Cosmochimica Acta, v. 65, p. 3,703-3,719, doi:10.1016/S0016-7037(01)00710-4.

Parker, A., 1970, An index of weathering for silicate rocks: Geological Magazine, v. 107, p. 501-504, doi:10.1017/S0016756800058581.

Plummer, L. N., and Busenberg, E., 1982, The solubility of calcite, aragonite and vaterite in $\mathrm{CO}_{2}-\mathrm{H}_{2} \mathrm{O}$ solution between $0^{\circ}$ and $90^{\circ} \mathrm{C}$ and an evaluation of the aqueous model for the system $\mathrm{CaCO}_{3}-\mathrm{CO}_{2}-\mathrm{H}_{2} \mathrm{O}$ : Geochimica et Cosmochimica Acta, v. 46, p. 1,011-1,040, doi:10.1016/0016-7037(82)90056-4

Plummer, L. N., Wigley, T. M. L., and Parkhurst, D. L., 1978, The kinetics of calcite dissolution in $\mathrm{CO}_{2}$-water systems at $5^{\circ}$ to $60^{\circ} \mathrm{C}$ and 0.0 to $1.0 \mathrm{~atm}$. $\mathrm{CO}_{2}$ : American Journal of Science, v. 278, p. 179-216.

Quervain, R. de, and Jenni, V., 1945, Verhalten der Bausteine gegen Witterungseinfluß: Beiträge zur Geologie der Schweiz, Geotechnische Serie 30.

Satoh, S., Nishimaru, Y., Tsukamato, K., Ueda, A., Kato, K., and Ueta, S. 2007, In situ measurement of dissolution of anorthite in $\mathrm{Na}-\mathrm{Cl}-\mathrm{OH}$ solutions at $22^{\circ} \mathrm{C}$ using phase shift interferometry: American Mineralogist, v. 92, p. 503-509, doi: 10.2138/am.2007.2153.

Schott, J., Berner, R. A., and Sjöberg, E. L., 1981, Mechanism of pyroxene and amphibole weathering. I. Experimental studies of iron-free minerals: Geochimica et Cosmochimica Acta, v. 45, p. 2,123-2,135, doi:10.1016/0016-7037(81)90065-X.

Sereda, P., 1974, Weather factors affecting the corrosion of metals, in Corrosion in natural environments: ASTM STP, American Society for Testing and Materials, v. 558, p. 7-22.

Stillings, L. L., Brantley, S. L., and Machesky, M. L., 1995, Proton adsorption at an adularia feldspar surface: Geochimica et Cosmochimica Acta, v. 59, n. 8, p. 1,473-1,482, doi:10.1016/0016-7037(95)00056-6.

Sverdrup, H. U., 1990, The kinetics of base cation release due to chemical Weathering: Lund, Sweden Lund University Press, 245 p.

Sverdrup, H. U., and Warfvinge, P., 1987, Kinetikken for produksjonen av katjoner ed vittringen av feltspatsmineraler (The kinetics of cation production of the weathering of feldspars): Technical Report, Department of Chemical Engineering II, Lund Institute of Technology, p. 33.

Tisserand, D., and Hellmann, R., 2008, Bridging the gap between laboratory dissolution and natural weathering: Geochimica et Cosmochimica Acta, v. 72, n. 12, Supplement \#1, p. A 948.

Tole, M. P., Lasaga, A. C., Pantano, C., and White, W. B., 1986, The kinetics of dissolution of nepheline $\left(\mathrm{NaAlSiO}_{4}\right)$ : Geochimica et Cosmochimica Acta, v. 50, p. 379-392, doi:10.1016/0016-7037(86)90191-2.

Urushibara-Yoshino, K., Miotke, F.-D., Research Group of Solution Rates in Japan, Kashima, N., Enomoto, H., Kuramoto, T., Kina, H., Nakahodo,T., and Higa, M., 1999, Solution rate of limestone in Japan: Physics and Chemistry of the Earth (A), Solid Earth and Geodesy, v. 24, n. 10, p. 899-903, doi:10.1016/ S1464-1895(99)00133-7.

Warscheid, Th., and Braams, J., 2000, Biodeterioration of stone: a review: International Biodeterioration \& Biodegradation, v. 46, p. 343-368, doi:10.1016/S0964-8305(00)00109-8.

Zhang, L., and Lüttge, A., 2007, Al, Si order in albite and its effect on albite dissolution processes: A Monte Carlo study: American Mineralogist, v. 92, p. 1,316-1,324, doi:10.2138/am.2007.2471. 